\title{
Mädätyksen vaikutus naudan lietelannan lannoitusominaisuuksiin nurmella
}

\author{
Petri Kapuinen, Paula Perälä ja Kristiina Regina \\ Maa- ja elintarviketalouden tutkimuskeskus, Kasvintuotannon tutkimus, Maaperä ja kasvinravitsemus, \\ 31600 Jokioinen, petri.kapuinen@mtt.fi
}

\section{Tiivistelmä}

Mädätyksen vaikutus lietelannan lannoitusarvoon on keskeinen kriteeri harkittaessa maatalouden biokaasutuotannon tukemista. Sen on väitetty parantavan merkittävästi lannan ravinteiden käyttökelpoisuutta ja hygieniaa korjattavan rehun laadun kannalta.

Väitteiden todenperäisyyden selvittämiseksi perustettiin 2-vuotinen kenttäkoe timotei-nurminata nurmelle Jokioisiin. Nurmea lannoitettiin keväällä väkilannoitteella $92 \mathrm{~kg} \mathrm{~N} / \mathrm{ha}$. Ensimmäisenä vuonna 1. niitto oli puhdistusniitto, mutta 2 . vuoden ruuduittainen edellisen vuoden käsittelyiden jälkivaikutusten selvittämiseksi. Tämän jälkeen koeruudut lannoitettiin koesuunnitelman mukaisesti. Tavoitteena oli käyttää naudan lietelantaa ns. nitraattiasetuksen sallima enimmäismäärä, $170 \mathrm{~kg}$ kok.-N/ha. Ennakkoanalyysien perustella tämän arvioitiin toteutuvan levitettäessä lietelantaa $85 \mathrm{~kg}$ liuk.-N/ha edestä. Mädätettyä lietelantaa käytettiin myös niin, että sen sisältämän kok.-N:n määrä oli $85 \mathrm{~kg} / \mathrm{ha}$ siltä varalta, että väittämät osoittautuisivat oikeiksi. Lietelannat levitettiin letkulevitys- tai sijoitustekniikalla. Lisäksi kenttäkokeessa oli typpilannoitusportaat: $0,50,75,100,125,150 \mathrm{ja} 175 \mathrm{~kg} \mathrm{~N} /$ ha väkilannoiteseoksella, jonka koostumus vastasi käytettyjen lietelantojen ravinnesuhteita. Nurmea ei lannoitettu 2. niiton jälkeen, mutta 3. sato korjattiin käsittelyiden jälkivaikutusten selvittämiseksi. Ammoniakkiemissioita mitattiin 3 päivää levityksestä ja kasvihuonekaasupäästöjä seuraavan kevään lannoitukseen asti.

Tulosten perusteella voidaan päätellä, että mädätys nostaa lannan lannoitusarvoa nurmenviljelyssä lähtökohtaisesti liukoisen typen osuuden kasvua vastaavasti. Liuk. N:n osuuden kasvaessa lietelannan osuus nurmen N-lannoituksesta voi kasvaa lannan kok.-N määrän ylittämättä ns. nitraattiasetuksen rajaa. Vastaavasti liuk. N:n määrän kasvaessa suhteessa fosforin määrään osuus typpilannoituksessa voi lisääntyä. Fosfori muodostuu uudessa ympäristötukijärjestelmässä yleensä rajoittavaksi, jos maan viljavuusluokka fosforin suhteen on vähintään hyvä.

Itse sadonmuodostuksessa mädätyksestä on merkittävää hyötyä vain, jos mädätetty lietelanta levitetään sijoitustekniikalla 1. niiton jälkeen. Tämä hyöty saadaan vain, jos myös 3. sato korjataan, mikä ei ole välttämättä taloudellisesti kannattavaa eikä edes mahdollista pohjoisimmilla tuotantoalueilla, vaikka olisikin ympäristölle hyödyksi. Lietelannan liuk. N tuottaa selvästi pienemmän sadon 2. niitossa kuin väkilannoite mädätyksestä ja sijoitustekniikan käytöstä huolimatta. Mädätys ei parantanut nurmisadon hygieniaa.

Sijoitustekniikan käytöllä vähennetään radikaalisti ammoniakkipäästöjä, liukoisen fosforin huuhtoutumista nurmilta sekä hajuhaittoja, joten sen positiiviset ympäristövaikutukset ovat huomattavat. Typpioksiduulipäästöt saattavat kuitenkin lisääntyä.

Ensimmäisen sadon muodostuksessa tarvittava typpi voidaan ja kannattaa antaa väkilannoitteena, koska väkilannoitteen levitykseen käytettävät koneet ovat keveämpiä ja siten sopivampia käytettäväksi keväällä märällä nurmella ja osa typpilannoituksesta joudutaan joka tapauksessa antamaan väkilannoitteena. Käytettäessä mädätettyä lietelantaa sijoitettuna ensimmäisen niiton jälkeen, toisen sadon liukoisen typen tarve voidaan lähes tyydyttää pelkällä lietelannalla, mutta mahdollisen kolmannen sadon lannoitus kannattaa antaa jo tässä yhteydessä väkilannoitteena tai mädättämätön lietelantaa käytettäessä 2 . sadon raakavalkuaispitoisuuden normalisoimiseksi. Toinen sato käyttää tämän typen ja vastaava määrä lietelannan typestä jää kolmannen sadon käyttöön.

Mädättämättömän lietelannan sijoittamisesta on sadonmuodostuksen kannalta lähinnä haittaa, mutta sen ympäristöhyödyt ovat lähes vastaavat kuin mädätetynkin lietelannan sijoittamisen. Sen liukoisen typen vaikutus jää pienemmäksi kuin mädätetyn lietelannan ja väkilannoitteen, mutta se voidaan useissa tapauksissa korvata väkilannoitetypellä kolmen niiton strategiassa, mikä kuitenkin lisää kustannuksia.

Asiasanat: nurmien lannoitus, karjanlanta, lietelanta, mädätys, sijoitus, timotei, nurminata, ravinnetappiot, typpi, fosfori, lannoitusarvo, ravinteiden käyttökelpoisuus, typpioksiduuli, hygienia, biokaasu, lisämateriaali 


\section{Johdanto}

Mädätyksen vaikutus lietelannan lannoitusarvoon on keskeinen kriteeri harkittaessa maatalouden biokaasutuotannon tukemista. Suomessa maatilakohtainen kannattava biokaasutuotanto vaatii Hagströmin ym.(2005) mukaan lisämateriaalien käyttöä, jos karja ei ole suuri, koska sitä ei Kalmarin (2006) mukaan tueta merkittävästi eikä tuotetulle sähkölle ole syöttötariffia kuten esimerkiksi Saksassa (BMU 2007). Suomessa kuitenkin suurin osa lannasta, Kapuisen (1994) mukaan noin 81 \%, on suhteellisen vähän kaasua tuottavaa naudanlantaa, ja karjakoko on tyypillisesti pieni. Samalla monivuotisten nurmien osuus karjatilojen viljelykierrossa on ollut suuri halvan viljan takia, ja pieni vilja-alakin korjataan usein kokoviljasäilörehuksi, jotta vältyttäisiin investoimasta sekä karkean rehun että puitavan viljan korjuukalustoon. Keski-Euroopassa lisämateriaalina käytetyn maissin ei ole tähän asti katsottu soveltuvan Suomessa viljeltäväksi, mutta sitä on viime vuosina koemittakaavassa viljelty aina Kainuuta myöten. Ennen sen viljelyn yleistymistä ja oikeiden viljelytekniikoiden ja lajikkeiden löytymistä luonnollinen biokaasuprosessin kasviperäinen lisämateriaali on monivuotisista nurmista korjattu biomassa, jota tuotetaan ja käsitellään kuten säilörehua.

Ruokintaan käytetyn säilörehun laatu on parhaimmillaan tehtynä ensimmäisen niittokerran sadosta (Huhtanen ym. 2006, 2007). Lietelannan levittäminen keväällä säilörehunurmeen lisää ensimmäisen niiton sadosta tehtävän säilörehun laaturiskejä, eikä peltojen kantavuus oikein riitä raskaalle lietelannan levityskalustolle. Lisäksi lietelannan käytöstä aiheutuvan satotappion merkitys ensimmäisen niittokerran sadossa on suurempi kuin seuraavissa, koska niittokertojen satojen osuudet ovat Tyynelän ym. (2004) mukaan keskimäärin $42 \%, 32 \%$ ja $26 \%$. Ensimmäisen niiton osuus kasvukauden sadosta on suurin timoteillä ja pienin englanninraiheinällä. Sen vuoksi on tarpeen siirtää lietelannan levitys mahdollisuuksien mukaan tehtäväksi vasta ensimmäisen niiton jälkeen, jolloin myös sen jälkeen muodostuva kasvusto on korjattava. Näiden satojen käyttö biokaasutuotannossa lisämateriaalina on hyvä vaihtoehto.

Tutkijat väittävät usein, että mädätetyn lietelannan ravinteet ovat kasveille käyttökelpoisempia kuin mädättämättömän. Mädätetyn lietelannan $\mathrm{pH}$ on korkeampi ja sen liukoisen typen pitoisuus on teoriassa korkeampi kuin mädättämättömän, joten voidaan olettaa, että myös ammoniakkiemissiot nurmen pintaan levitetystä mädätetystä lietelannasta ovat suuremmat kuin mädättämättömästä (Mattila ja Joki-Tokola 2003). Näiden väitteiden ja oletusten tarkistamiseksi perustettiin Jokioisiin (P6047,9' I232 26,3') hiesusavipellolle kenttäkoe timotei-nurminata- nurmelle vuosiksi 2005 ja 2006.

\section{Aineisto ja menetelmät}

Nurmi lannoitettiin pelkällä väkilannoitetypellä (92 kg/ha) kumpanakin keväänä. Ensimmäisen niiton sato mitattiin toisena mutta ei ensimmäisenä koevuotena. Lannoituskäsittelyt toistettiin samoilla tavoilla samoihin koeruutuihin kumpanakin vuonna sovelletussa satunnaistetussa osaruutulohkokokeessa, jossa pääruututekijänä oli lantalaji, mädättämätön ja mädätetty, ja osaruututekijänä levitysmenetelmä. Tavoitteena oli käyttää lietelantaa lainsäädännön ja ympäristötukijärjestelmän sallima suurin määrä. Tämän vuoksi mädättämättömän lietelannan levitysmäärä asetettiin niin, että karjanlannasta tulevan kokonaistypen määräksi tuli $170 \mathrm{~kg} / \mathrm{ha}$ (ETY 1991, VN 2000). Mädätettynä lietelantana annettavan liukoisen typen tavoitemäärä oli sama kuin mädättämättömänä annetun eli noin $85 \mathrm{~kg} / \mathrm{ha}$. Mädätettyä lietelantaa levitettiin lisäpääruututekijän tasossa kokonaistypen pitoisuuden perusteella samainen $85 \mathrm{~kg} / \mathrm{ha}$ siltä varalta, että väitteet mädätyksen suuresta vaikutuksesta lannan kokonaistypen käyttökelpoisuuteen osoittautuisivat todeksi ja liukoisen typen pitoisuuden mukainen taso johtaisi selvään ylilannoitukseen. Lisäksi kokeessa oli typpitasot: $0,50,75,100,125,150 \mathrm{ja} 175 \mathrm{~kg} /$ ha pintaan levitettynä väkilannoitteena, jossa pääravinteiden suhteet vastasivat mahdollisimman hyvin lietelantojen vastaavaa. Kolmatta satoa ei lannoitettu erikseen, vaan siitä mitattiin toisen sadon korjuun jälkeen käsittelyistä jäljelle jäävä lannoittiøiseikikjukxolmannen niiton kuiva-ainesato ja raakavalkuaispitoisuus määritettiin molempina vuosina. Lisäksi lannoituskäsittelyiden jälkeen mitattiin kolmen päivän ajan ammoniakkiemissiota. Typpioksiduulipäästöä mitattiin ensimmäisen vuoden lantakäsittelyistä eteenpäin ympäri vuoden toista vuotta seuraavan vuoden kevätlannoitukseen asti.

\section{Tulokset ja tulosten tarkastelu}

Tulosten perusteella lannan lannoitusarvon lisäyksen mädätyksessä voidaan katsoa lähtökohtaisesti vastaavan liukoisen typen osuuden kasvua kokonaistypestä. Samalla lannan fosforipitoisuus suhteessa liukoisen typen pitoisuuteen pienenee. Tämä sallii kasvattaa lietelannan osuutta nurmen typpilannoituksessa 
ylittämättä nitraattidirektiivin (ETY 1991) ja sen implementoimiseksi annetun kansallisen lainsäädännön (VN 2000) asettamaa rajaa karjanlannasta tulevalle kokonaistypen määrälle ja toisaalta ympäristötukijärjestelmän asettamaa rajaa fosforilannoitukselle (MMM 2007). Esimerkiksi vuonna 2006 liukoisen typen määrät mädättämättömästä ja mädätetystä lietelannasta olivat $97 \mathrm{ja} 103 \mathrm{~kg} / \mathrm{ha}$, kasveille käyttökelpoisen fosforin $24,9 \mathrm{~kg} / \mathrm{ha}$ ja $19,6 \mathrm{~kg} / \mathrm{ha}$ ja kaliumin $200 \mathrm{ja} 220 \mathrm{~kg} / \mathrm{ha}$ kokonaistypen määrän ollessa $170 \mathrm{~kg} / \mathrm{ha}$. Kaliumlannoitus muodostui hieman liian suureksi, mikä saattoi haitata nurmikasvien kaksiarvoisten kationien ottoa ja altistaa naudat ruokinnallisille sairauksille. Meidän strategiamme oli kuitenkin käyttää toinen ja kolmas sato biokaasutuotannon lisämateriaalina.

Vuonna 2005 toisen niiton kuiva-ainesato kasvoi typpilannoitustasolle $125 \mathrm{~kg} / \mathrm{ha}$ saakka. Kolmannen niiton kuiva-ainesato kasvoi tasolle $175 \mathrm{~kg} \mathrm{~N} / \mathrm{ha}$ saakka eli kasvukauden tasolle $267 \mathrm{~kg} \mathrm{~N} / \mathrm{ha}$ saakka, kun nykyisen ympäristötukijärjestelmä (MMM 2007) sallii enimmillään $240 \mathrm{~kg}$ /ha maalajista ja tuotantoalueesta riippuen. Toisen sadon muodostumisessa käyttämättä jäänyt typpi tuli käytettyä kolmannen sadon muodostuksessa. Suuremman määrän kuin $125 \mathrm{~kg} \mathrm{~N} / \mathrm{ha} \mathrm{käyttö} \mathrm{ei} \mathrm{ole} \mathrm{kuitenkaan} \mathrm{edes} \mathrm{vain} \mathrm{lannoitekustan-}$ nukset huomioon ottaenkaan enää taloudellisesti mielekästä, joten taloudellisesti paras satotaso voitiin saavuttaa ympäristötukijärjestelmän (MMM 2007) puitteissa.

Lietelannan ravinnepitoisuuksien ollessa käyttämämme lietelannan suuruiset lietelannan lisäksi olisi voitu käyttää noin $40 \mathrm{~kg} /$ ha väkilannoitteen liukoista typpeä 2. ja 3. sadolle lietelannasta tulevan kokonaistypen määrän ollessa $170 \mathrm{~kg} / \mathrm{ha}$. Toteutuneet liukoisen typen määrät mädättämättömästä ja mädätetystä lietelannasta olivat vuonna 2005 vain $64,9 \mathrm{ja} 72,5 \mathrm{~kg} / \mathrm{ha}$ ja vastaavasti $73,9 \mathrm{ja} 77,2 \mathrm{~kg} / \mathrm{ha}$ vuonna 2006 , koska ennakkoanalyyseissä lietelannan liukoisen typen pitoisuudet olivat lopullisten analyysien vastaavia suuremmat. Vuosittain separoimattomasta lietelannasta saatava liukoisen typen määrä voi olla korkeintaan noin $100 \mathrm{~kg}$ /ha ylittämättä sallittua karjanlannasta tulevaan kokonaistypen määrää (ETY 1991, VN 2000), jolloin typpilannoitus joudutaan joka tapauksessa antamaan väkilannoitteena siltä osin kuin se ylittää 100 $\mathrm{kg} / \mathrm{ha}$ eli käytännössä ensimmäisen ja kolmannen sadon tarve, noin $140 \mathrm{~kg} / \mathrm{ha}$, kenttäkokeemme viljelyolosuhteissa.

Nurmen pintaan levitetyn käsittelemättömän lietelannan liukoisen typen tappiot ammoniakkina voivat olla $30-40 \%$ ja käsitellyn $60 \%$ (Mattila ja Joki-Tokola 2003, Mattila ym. 2003). Vuonna 2005 toisen niiton mitatut kuiva-ainesadot lietelantakäsittelyistä vastasivat tämän suuruisten typen tappioiden jälkeen jäljelle jäävää tehollista typpilannoitusta. Mädättämättömän mutta sijoitetun lietelannan liukoinen typpi tuotti merkitsevästi 29 \% pienemmän kuiva-ainesadon kuin väkilannoitteen typpi toisessa niitossa (taulukko 1). Aineiston hajonta oli toisen ja kolmannen niiton suhteellisen pienissä sadoissa verraten suuri, minkä takia myös merkitseviksi muodostuvat erot olivat verraten suuret. Mädätetyn ja sijoitetun lietelannan tuottama mitattu 2. kuiva-ainesato oli $14 \%$ pienempi kuin väkilannoitteella saatu. Letkulevitetyn mädättämättömän lietelannan tuottama mitattu sato oli $17 \%$ pienempi kuin väkilannoitteella saatu, ja vastaavasti letkulevitty mädätetty lietelanta tuotti merkitsevästi $20 \%$ pienemmän kuiva-ainesadon kuin väkilannoite. Letkulevitystekniikkaa käyttäen mädättämättömän ja mädätetyn lietelannan tuottamissa kuivaainesadoissa ei ollut juuri eroa eikä mädätetty lietelanta tuottanut sijoitettuna merkitsevästi suurempaa satoa kuin letkulevitettynä. Sen sijaan mädättämättömän lietelannan sijoittaminen letkulevityksen sijaan alensi kuiva-ainesatoa merkitsevästi. Sijoitetun lietelannan typen tappiot ammoniakkina ovat Mattilan ja Joki-Tokolan (2003) mukaan marginaaliset, joten sijoitetun mädättämättömän lietelannan tuottaman pienen kuiva-ainesadon täytyy olla seurausta joistakin maassa syntyvistä negatiivisista prosesseista. Tulos viittaa siihen, että mädättämätöntä lietelantaa ei pitäisi sijoittaa, jos kriteerinä on kuiva-ainesato.

Sijoitetun mädätetyn lietelannan typpi tuotti 2 . niitossa hieman (14 \%), joskaan ei merkitsevästi pienemmän kuiva-ainesadon kuin väkilannoitteen typpi (taulukko 1). Mädätetyn lietelannan liukoista typpeä voidaan levittää jonkin verran enemmän kuin mädättämättömän kokonaistypen levitysmäärän pysyessä $170 \mathrm{~kg} /$ ha ja hyödyntäen karjanlannan fosforin käyttömäärän poikkeuksia, joten väkilannoitteella saatavan kuiva-ainesadon veroisia satoja voidaan saavuttaa levittämällä mädätettyä lietelantaa liukoisen typen määrällä mitattuna jonkin verran enemmän kuin väkilannoitetta.

Väkilannoitetypen käyttö lietelannan täydennyslannoitteena on välttämätöntä rehukäytössä, jos lietelantaa ei ole mädätetty, koska mädättämättömällä lietelannalla saadun 2. sadon raakavalkuaispitoisuus oli vain 9,0-9,5\% normaalin väkilannoitteella tasolla $75 \mathrm{~kg} \mathrm{~N} /$ ha saavutetun pitoisuuden olleessa $12,7 \%$ (taulukko 1). Normaali raakavalkuaispitoisuus 11,2-13,2\% saavutettiin käyttämällä mädätettyä lietelantaa. Mädätys nosti raakavalkuaispitoisuutta 2,3\%-yksikköä ja sijoitus 0,8 \%-yksikköä. Sijoituksella ja mädätyksellä on positiivinen yhdysvaikutus. Ne yhdessä nostivat raakavalkuaispitoisuutta 3,6 \%.

Kun mädättämätön lietelanta sijoitettiin, 2. sadon typen näennäinen hyväksikäyttö oli erittäin pieni, 
vain $10 \%$, kun sijoittamalla mädätettyä lietelantaa saavutettiin samanlainen typen näennäinen hyväksikäyttö (50,0 \%) kuin väkilannoitteella (54,6 \%) (taulukko 1). Pelkkä mädätyskin paransi typen hyväksikäyttöä merkitsevästi 17,7 \%:sta 32,0 \%:iin. Mädättämättömän lietelannan sijoittamien sen sijaan alensi sekä toisen että kolmannen niiton raakavalkuaissatoa.

Taulukko 1. Lantalajin ja levitysmenetelmän vaikutus nurmisatoon vuonna 2005

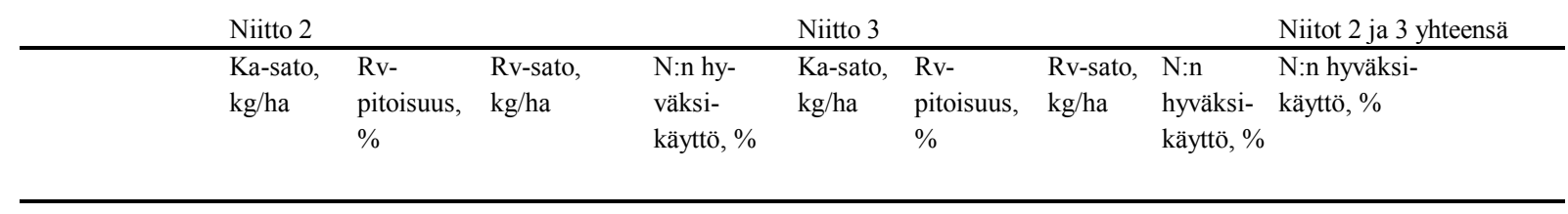

\begin{tabular}{|c|c|c|c|c|c|c|c|c|c|}
\hline \multicolumn{10}{|l|}{ Lantalaji } \\
\hline Mädättämätön & 2748 & 9,7 & 268 & 13,7 & 679 & 14,9 & 101 & 8,8 & 22,5 \\
\hline Mädätetty & 3104 & 12,0 & 383 & 41,3 & 778 & 14,1 & 108 & 10,8 & 52,0 \\
\hline F-arvo & 7,92 & 22,76 & 69,13 & 214,22 & 2,97 & 3,71 & 0,90 & 2,49 & 126,66 \\
\hline Vapausasteet & $1,7,5$ & $1,3,05$ & 1,11 & 1,10 & 1,11 & $1,6,25$ & $1,8,38$ & 1,10 & 1,10 \\
\hline p-arvo & $0,0242 *$ & $0,0168 *$ & $<0,0001^{* * *}$ & $0,0001 * * *$ & 0,1130 & 0,1010 & 0,3700 & 0,1460 & $0,0002 * * *$ \\
\hline \multicolumn{10}{|l|}{ Levitysmenetelmä } \\
\hline Sijoitus & 2904 & 11,3 & 336 & 30,2 & 768 & 14,1 & 106 & 10,4 & 40,7 \\
\hline Letkulevitys & 2949 & 10,5 & 316 & 24,8 & 690 & 14,9 & 103 & 9,1 & 33,9 \\
\hline F-arvo & 0,12 & 20,19 & 2,17 & 8,38 & 1,86 & 7,49 & 0,24 & 1,11 & 6,64 \\
\hline Vapausasteet & $1,7,79$ & $2,5,19$ & 1,11 & 1,10 & 1,11 & $1,5,92$ & $1,8,38$ & 1,10 & 1,10 \\
\hline p-arvo & 0,7396 & $0,0059 * *$ & 0,1680 & $0,0160 *$ & 0,2000 & $0,0344 *$ & 0,6400 & 0,3160 & $0,0276^{*}$ \\
\hline \multicolumn{10}{|c|}{ Lantalaji*levitysmenetelmä } \\
\hline \multicolumn{10}{|l|}{ Mädättämätön } \\
\hline Sijoitus & $2500^{\mathrm{a}}$ & $9,5^{\mathrm{a}}$ & $239^{\mathrm{a}}$ & $10,0^{\mathrm{a}}$ & $634^{\mathrm{a}}$ & 14,8 & 94 & 8,4 & $18,3^{\mathrm{a}}$ \\
\hline Letkulevitys & $2996^{\mathrm{ab}}$ & $9,9^{\mathrm{a}}$ & $298^{\mathrm{b}}$ & $17,5^{\mathrm{a}}$ & $724^{\mathrm{ab}}$ & 15,0 & 108 & 9,3 & $26,8^{\mathrm{b}}$ \\
\hline \multicolumn{10}{|l|}{ Mädätetty } \\
\hline Sijoitus & $3308^{\mathrm{b}}$ & $13,1^{\mathrm{b}}$ & $433^{c}$ & $50,5^{\mathrm{c}}$ & $901^{\mathrm{b}}$ & 13,3 & 119 & 12,5 & $63,0^{\mathrm{d}}$ \\
\hline Letkulevitys & $2901^{\mathrm{ab}}$ & $11,0^{\mathrm{a}}$ & $333^{\mathrm{b}}$ & $32,0^{\mathrm{b}}$ & $655^{\mathrm{ab}}$ & 14,8 & 97 & 9,0 & $41,0^{\mathrm{c}}$ \\
\hline F-arvo & 12,22 & 43,24 & 33,05 & 47,89 & 8,54 & 3,99 & 5,76 & 3,25 & 33,88 \\
\hline Vapausasteet & $1,7,79$ & $1,5,19$ & 1,11 & 1,10 & 1,11 & $1,5,92$ & $1,8,38$ & 1,10 & 1,10 \\
\hline p-arvo & $0,0085 * *$ & $0,0011^{* *}$ & $0,0001 * * *$ & $0,0001 * * *$ & $0,0139 *$ & 0,0940 & $0,0418^{*}$ & 0,1020 & $0,0001 * * *$ \\
\hline
\end{tabular}

Vertailu väkilannoitukseen

\begin{tabular}{|c|c|c|c|c|c|c|c|c|c|}
\hline Lannoite & & & & Sijoitus & & & & & \\
\hline Mädättämätön & $2500^{\mathrm{a}}$ & $9,5^{\mathrm{a}}$ & $239^{\mathrm{a}}$ & $10,0^{\mathrm{a}}$ & $632^{\mathrm{a}}$ & 14,8 & $93,6^{\mathrm{ab}}$ & 8,4 & $18,3^{\mathrm{a}}$ \\
\hline Mädätetty & $3256^{\mathrm{b}}$ & $13,2^{\mathrm{b}}$ & $433^{b}$ & $50,5^{b}$ & $893^{\mathrm{b}}$ & 13,3 & $119,3^{\mathrm{b}}$ & 12,5 & $63,4^{b}$ \\
\hline Väkilannoite & $3601^{\mathrm{b}}$ & $12,5^{\mathrm{b}}$ & $451^{\mathrm{b}}$ & $54,6^{\mathrm{b}}$ & $640^{\mathrm{ab}}$ & 13,3 & $85,4^{\mathrm{a}}$ & 6,8 & $61,7^{\mathrm{b}}$ \\
\hline F-arvo & 20,97 & 15,25 & 128,94 & 148,13 & 6,14 & 4,73 & 6,68 & 4,46 & 70,3 \\
\hline Vapausasteet & $2,3,4$ & 2, 4,09 & 2,6 & 2,6 & 2,7 & 2,7 & 2,7 & 2,7 & $2,2,3$ \\
\hline p-arvo & $0,0122 *$ & $0,0127^{*}$ & $0,0001^{* * *}$ & $0,0001^{* * *}$ & $0,0288^{*}$ & 0,0500 & $0,0238^{*}$ & 0,5600 & $0,0087 * *$ \\
\hline Lannoite & & & & Letkulevitys & & & & & \\
\hline Mädättämätön & $2996^{\mathrm{ab}}$ & $9,9^{\mathrm{a}}$ & $298^{\mathrm{a}}$ & $17,7^{\mathrm{a}}$ & 724 & $15,0^{\mathrm{a}}$ & 108 & 9,3 & $26,8^{\mathrm{a}}$ \\
\hline Mädätetty & $2879^{\mathrm{a}}$ & $11,0^{\mathrm{ab}}$ & $333^{\mathrm{a}}$ & $32,0^{\mathrm{ab}}$ & 655 & $14,8^{\mathrm{a}}$ & 97 & 9,0 & $41,0^{b}$ \\
\hline Väkilannoite & $3596^{\mathrm{b}}$ & $12,6^{\mathrm{b}}$ & $451^{\mathrm{b}}$ & $55,2^{\mathrm{c}}$ & 647 & $13,2^{\mathrm{b}}$ & 85 & 6,8 & $61,9^{\mathrm{c}}$ \\
\hline F-arvo & 7,87 & 12,13 & 18,01 & 132,78 & 0,49 & 7,48 & 1,69 & 1,64 & 54,87 \\
\hline Vapausasteet & 2, 4,46 & $2,4,47$ & 2,7 & $2,3,85$ & 2,8 & 2, 5,35 & 2,8 & 2,7 & $2,3,97$ \\
\hline p-arvo & $0,0345 *$ & $0,0156^{*}$ & $0,0017 * *$ & $0,0003^{* * *}$ & 0,6310 & $0,0282 *$ & 0,2441 & 0,2610 & $0,0013^{* *}$ \\
\hline
\end{tabular}

Vaikka toisen niiton kuiva-ainesato kasvoi vuonna 2005 typpilannoitustasolle $125 \mathrm{~kg} / \mathrm{haja}$ raakavalkuais- 
pitoisuus typpilannoitustasolle $175 \mathrm{~kg} / \mathrm{ha}$, typpilannoitustasoa ei ole tarvetta nostaa yli $100 \mathrm{~kg} / \mathrm{ha}$ raakavalkuaispitoisuuden kasvattamiseksi. Ympäristötukijärjestelmä (MMM 2007) salli kahdelle niittokerralle $200 \mathrm{~kg} \mathrm{~N} / \mathrm{ha}$ eli lähes taloudellisesti optimaalisen kuiva-ainesadon tuottamiseen tarvittavan typpilannoitusmäärän $(92+125=217 \mathrm{~kg} \mathrm{~N} / \mathrm{ha})$. Koska vain $60 \%$ tai vähemmän lietelannan liukoisesta typestä on tuotantovaikutukseltaan väkilannoitteen typen veroista, jos sitä ei ole mädätetty ja sijoitettu, lietelannan käyttö potentiaalisesti alentaa kuiva-ainesatoa ympäristötukijärjestelmän (MMM 2007) sallimilla typpilannoitustasoilla kahden niiton strategiassa.

Vuoden 2005 kolmannen niiton kuiva-ainesato oli verraten pieni, alle $1 \mathrm{t} /$ ha kuiva-ainetta (taulukko 1). Näin pienen sadon korjuun kannattavuus on kyseenalainen. Vaikka ympäristötukijärjestelmä sallii käyttää korkeampaa (125 kg N/ha) lannoitustasoa, saadaan yhteensä vain $926 \mathrm{~kg} / \mathrm{ha}$ suurempi kuivaainesato huomioimatta vaikutuksia seuraavan vuoden ensimmäiseen satoon kuin käyttämällä $100 \mathrm{~kg} \mathrm{~N} / \mathrm{ha}$ ja vain kahta niittoa. Kun typpilisää ei voi antaa separoimattomana lietelantana, ei tätä voi perustella suuremmalla lannankäyttömahdollisuudellakaan. Sijoitetun mädätetyn lietelannan tuottama mitattu kolmas kuiva-ainesato oli $40 \%$ ja letkulevitetyn mädättämättömän lietelannan $12 \%$ suurempi kuin vastaavan typpilannoitustason väkilannoitteella lannoitettuna. Tästä seurasi se, että nämä lietelantakäsittelyt paransivat merkittävästi asemiaan, kun nurmi niitettiin myös kolmannen kerran. Toisen ja kolmannen niiton yhteen laskettu kuiva-ainesato mädätetyllä ja sijoitetulla lietelannalla tuotettuna oli vain 10,6\%, mädätetyllä mutta letkulevitetyllä 13,7 \% ja mädättämättömällä letkulevitetyllä $16,2 \%$ pienempi kuin väkilannoitteella tuotettuna. Sen sijaan mädättämätön ja sijoitettu lietelanta tuotti peräti $30 \%$ pienemmän kuiva-ainesadon kuin väkilannoite. Jos tarkastellaan kasvukauden kolmen niiton yhteiskuiva-ainesatoa, satotappio lietelannan käytöstä on noin $60 \%$ edellä mainituista, jolloin se jää parhailla käsittelyillä verraten pieneksi. Tällöin ainoastaan sijoitettu mädättämätön lietelanta tuotti merkittävästi huonomman tuloksen kuin väkilannoite. Lietelannan lannoitusvaikutuksen täysimääräinen hyödyntäminen edellyttää myös kolmatta niittoa, mikä ei välttämättä ole mahdollista pohjoisilla tuotantoalueilla. Sen taloudellinen merkitys lisäkustannukset huomioon ottaen saattaa olla kyseenalainen, mutta ympäristön kuormituksen kannalta se on oleellinen. Kolmannella niitolla voi kuitenkin olla myös positiivisia vaikutuksia seuraavan vuoden sadon määrään ja laatuun.

Vuoden 2005 kolmannen niiton satojen raakavalkuaispitoisuus oli 13,2 - 15,0 \%. Mädätetyllä ja sijoitetulla lietelannalla saatu kolmas raakavalkuaissato oli merkitsevästi 39,7 \% parempi kuin väkilannoitteella saavutettu. Suurikaan typpilannoitus $(175 \mathrm{~kg} / \mathrm{ha})$ ensimmäisen niiton jälkeen ei tuottanut merkittävää parannusta kolmannen niiton raakavalkuaissatoon.

Vuonna 2005 yhdistetyn toisen ja kolmannen niiton sadon liukoisen typen näennäinen hyväksikäyttö oli käsittelyssä, jossa mädättämätön lietelanta sijoitettiin 18,3\%, mikä oli merkitsevästi pienempi kuin käsittelyssä, jossa mädätetty lietelanta sijoitettiin $(63,4 \%)$ ja käytettiin väkilannoitetta $(61,7 \%)$. Käsittelyssä, jossa mädättämätön lietelanta oli letkulevitetty, se oli $26,8 \%$, ja käsittelyssä, jossa mädätetty lietelanta oli letkulevitetty, se oli 41,0 \%. Letkulevitys käsittelyiden keskinäinen ero ja ero väkilannoituskäsittelyyn oli merkitsevä.

Vuoden 2006 ensimmäisen niiton kuiva-ainesato oli normaali tai jopa sitä suurempi, keskimäärin $5365 \mathrm{~kg} / \mathrm{ha}$. Se sisälsi keskimäärin $15 \mathrm{~kg} / \mathrm{ha}$ enemmän typpeä kuin mitä oli kevätlannoituksessa annettu. Typen näennäinen hyväksikäyttö oli siten keskimäärin $116 \%$, mikä on lähes kaksinkertainen verrattuna esimerkiksi vuoden 2005 parhaan toisen ja kolmannen sadon typen näennäisen hyväksikäytön antaneisiin käsittelyihin. Vuoden 2006 ensimmäisen niiton sadolla mitattiin vuoden 2005 käsittelyiden jälkivaikutuksia. Lehmän vuodessa tuottamassa lannassa on noin $100 \mathrm{~kg}$ kokonaistyppeä (FME 2002). Näin ollen lehmän lannan levitykseen tarvitaan vähintään 0,59 ha peltoa, jotta kokonaistypen sallittu määrä ei ylity (ETY 1991, VN 2000). Tämän suuruinen nurmiala voisi vuoden 2006 ensimmäisen niiton satotasolla tuottaa kuiva-ainetta $3155 \mathrm{~kg}$, joka sisältää 2967 ry:ä. $500 \mathrm{~kg}: n$ massainen lehmä pystyisi tuottamaan $7040 \mathrm{~kg}$ energiakorjattua maitoa ja vasikan vuosittain tällä nurmirehumäärällä, jos väkirehusta tulevan energian määrä olisi tyypillinen 55 \% kokonaistarpeesta (MTT 2006). Olettaen, että lehmä on ympärivuotisesti sisäruokinnassa, ensimmäinen nurmisato väkirehun lisäksi olisi riittäisi ruokintaan ja toinen ja kolmas nurmisato voitaisiin käyttää muihin tarkoituksiin, kuten biokaasureaktorin lisämateriaaliksi.

Vuoden 2006 lietelantakäsittelyiden toisen niiton kuiva-aine sato oli erittäin pieni, koska niiton ja lannoituskäsittelyiden välillä oli hyvin kuiva kausi. Toisen niiton kuiva-ainesadot olivat vain $588-1022$ $\mathrm{kg} / \mathrm{ha}, 10,4-19,2 \%$ ensimmäisen niiton kuiva-ainesadoista, kun vuonna 2005 toisen niiton kuiva-ainesato oli keskimäärin $2926 \mathrm{~kg} / \mathrm{ha}$. Mädättämätön liete ei lisännyt lainkaan kuiva-ainesatoa verrattuna lannoittamattomaan käsittelyyn ja sen tuottama typpisato oli pienempi kuin lannoittamattoman. Kuivuuden yleinen 
vaikutus lietelannan sadontuotantokykyyn oli samankaltainen kuin väkilannoitteen vastaavaan. $75 \mathrm{~kg} \mathrm{~N} / \mathrm{ha}$ saanut käsittely tuotti myös vain $832 \mathrm{~kg} /$ ha kuiva-ainetta. Hyvin epätavallisten sääolosuhteiden takia vuoden 2006 aineiston perustella ei voida tehdä yleisiä päätelmiä käsittelyiden vaikutuksista, vaan ainoastaan käsittelyiden vaikutuksista hyvin kuivana keskikesänä.

Vaikka letkulevitetyn lietelannan typpi ei tullut hyödynnettyä toisen sadon muodostuksessa, se ei juuri tullut hyödynnettyä kolmannenkaan sadon muodostuksessa, koska kolmannen niiton kuiva-ainesadot olivat suurin piirtein samat kuin vuonna 2005. Letkulevitetyn lietelannan typen satovaikutus oli kuivissa olosuhteissa selvästi huonompi kuin väkilannoitteen typen. Väkilannoituskäsittelyiden kolmas kuivaainesato oli sen sijaan noin kaksinkertainen verrattuna vuoden 2005 vastaavaan. Lietelannan typpi ei näytä säilyvän nurmessa edes elo-syyskuuhun saakka, jos se on levitetty välittömästi ensimmäisen niiton jälkeen ja se jää käyttämättä toisen niiton sadon muodostuksessa. Sen sijaan sijoitetun lietelannan typpi tuotti merkitsevästi 26,3 \% paremman kuiva-ainesadon, 40,3 \% paremman raakavalkuaissadon ja 84,5\% paremman näennäisen typen hyväksikäytön kuin letkulevitetyn. Kolmannen niiton sadon osuus kasvukauden satotuloksesta oli vain $11,7 \%$, joten sijoittaminen letkulevityksen sijasta ei liene tästä huolimatta taloudellisesti mielekästä.

Tarkasteltaessa kahden viimeisen niiton yhteisiä satotuloksia voidaan todeta, että mädätetyn lietelannan typpi tuotti 26,8 \% paremman kuiva-ainesadon ja 45,5 \% suuremman kuiva-aine sadon kuin mädättämätön ja että sijoittamisesta ei ollut haittaa, vaikka sen jälkeen ennen toista niittoa ei satanut juuri lainkaan. Sijoituskäsittelyistä saatu pieni toinen sato tuli kompensoitua kolmannella niittokerralla ja mädätyksen positiivinen vaikutus oli ratkaisevampi kuin levitystapa. Mädätys paransi typen näennäisen hyväksikäytön samalle tasolle kuin väkilannoitteen vastaavan kanssa, joka oli viisinkertainen mädättämättömällä saavutettuun verrattuna. Tästä huolimatta se oli vain noin $22 \%$, kun vastaava luku vuonna 2005 oli $62 \%$. Jos lietelanta sijoitetaan ensimmäisen niiton jälkeen ja sen jälkeen ei juuri sada ennen toista niittoa, niin kolmannen sadon korjaaminen on tärkeää ainakin ympäristön kuormituksen vähentämiseksi.

Sijoittaminen vähensi radikaalisti ammoniakkiemissioita ja ilmeisesti myös hajuhaittoja sekä fosforin huuhtoutumista nurmen pinnasta tuottaen merkittävän ympäristöhyödyn, vaikka sijoittamisen lisäkustannus saattaa jäädä kattamatta satohyödyllä. Samalla kuitenkin typpioksiduulipäästöt lisääntyivät levityksen jälkeen. Typpioksiduulipäästöt ovat suurimmillaan juuri levityksen jälkeen ja lumen sulaessa keväällä. Lantakäsittelyiden kumuloitu typpioksiduulipäästö ei kuitenkaan eroa merkitsevästi väkilannoitteen vastaavasta, joten levityksen jälkeisten erojen merkitys jää vähäiseksi. Mädättämättömän lietelannan sijoittamisen positiiviset ympäristövaikutukset eivät ole yhtä yksiselitteiset kuin mädätetyn, koska kyseisessä tapauksessa typen hyväksikäyttö jäi huonoksi, mikä huonontaa kokonaistulosta ja pakottaa arvottamaan typpi- ja fosforikuormitusta toisiinsa nähden.

Mädätys vähentää jossain määrin lietelannan hygieniaindikaattoreiden enterbakteerien ja fekaalisten streptokokkien määrää. Vuonna 2005 enterobakteerien, fekaalisten streptokokkien ja kolifomien määrä oli maassa koholla käsittelyissä, joissa oli käytetty mädättämätöntä lietelantaa. Vuonna 2006 lantojen välillä ei ollut tässä mielessä eroa, mutta enterobakteerien ja koliformien määrä oli lantakäsittelyissä koholla vielä kolme viikkoa levityksen jälkeen. Kasvustoista ei kuitenkaan löydetty kohonneita hygieniaindikaattoreiden määrï̈ kumpanakaan vuonna toisen niiton yhteydessä.

\section{Johtopäätökset}

Suomessa maa on keväällä liian märkää lietteen levityskalustolle silloin kuin kevätlannoitus tulisi tehdä. Sen tähden nurmi on järkevintä lannoittaa keväällä väkilannoitteella, joka ei sisällä fosforia, koska väkilannoitteenlevityskalusto on kevyempää kuin lietelannan. Kevätlannoituksen typen hyväksikäyttö on tehokkaampaa kuin myöhempien lannoituskertojen. Osa typpilannoituksesta, enimmillään noin $140 \mathrm{~kg} / \mathrm{ha}$, on joka tapauksessa annettava väkilannoitteena, koska suurin sallittu liukoisen typen määrä on $240 \mathrm{~kg} / \mathrm{ha}$ ja lannasta tulevan kokonaistypen suurin sallittu määrä on $170 \mathrm{~kg} / \mathrm{ha}$ ja siitä vain runsaat puolet on liukoisessa muodossa. Ensimmäisen niiton sadon määrä ja laatu ovat yleensä paremmat kuin myöhempien. Lietelannan, jota ei oltu mädätetty tai sijoitettu, käyttö ainakin jossain määrin alensi sadon määrää, raakavalkuaispitoisuutta tai -satoa seuraavissa niitoissa ja saattaa vaarantaa rehun laadun sekä lisätä ympäristön kuormitusta. Satotappioiden potentiaalinen merkitys on potentiaalisesti sekä absoluuttisesti että suhteellisesti pienempi toisessa ja kolmannessa niitossa kuin ensimmäisessä. Kun lietelanta levitetään vasta ensimmäisen niiton jälkeen, kasvukauden satotappiot ovat pienimmät. Vasta toisen niiton jälkeen tehtävä levitys olisi liian myöhäinen lannan typen hyväksikäytön kannalta ja vain väkilannoitetta pitäisi voida käyttää. Lietelannan mädätyksen ja ensimmäisen niiton jälkeen tehtävän sijoituksen ja kolmannen niiton 
positiiviset vaikutukset typen hyväksikäyttöön ovat selvästi suuremmat kuin kuiva-ainesatoon, mikä korostaa lietelannan tällaisen käytön ympäristöystävällistä luonnetta. Ensimmäisen niiton jälkeen sijoitettu mädätetty lietelanta tuottaa kuitenkin myös sadon, joka on verrannollinen väkilannoitteella saatavaan. Koska ensimmäisen niittokerran sato on määrällisesti ja laadullisesti suurin tässäkin lietelannan käyttöstrategiassa, se kannattaa käyttää ensisijaisesti ruokintaan. Myöhempien niittokertojen sato voidaan käyttää esimerkiksi biokaasureaktorissa lisämateriaalina. Sijoitus tehostaa mädätyksen positiivista vaikutusta. Kustannuksia lisäävää väkilannoitetyppitäydennystä on käytettävä, jos lietelanta ei ole mädätetty 2. sadon normaalin raakavalkuaispitoisuuden saavuttamiseksi. Mädätyksessä samasta lietelantamäärästä saatava liukoisen typen määrä ja sen myötä lannoitusarvo kasvavat liukoisen typen määrän kasvua vastaavasti. Lisäksi se mahdollistaa suuremman osan nurmen typpilannoitustarpeesta kattamisen lietelannalla nitraattiasetuksen puitteissa. Mädättämättömän lietelannan sijoittaminen vähentää ammoniakkiemissioita ja liukoisen fosforin huuhtoutumista, mutta jättää avoimeksi huonon typen hyväksikäytön merkityksen muun muassa vesistökuormitukselle. Lietteen käyttö lisää hygieniariskejä ja sen sijoitus typpioksiduulipäästöjä välittömästi levityksen jälkeen mutta sadonkorjuuvaiheessa hygieniariski ei ole suurempi kuin väkilannoitetta käytettäessäkään eikä vuoden kumuloituva typpioksiduulipäästö ole sijoitetusta lietelannasta suurempi kuin väkilannoitteesta.

\section{Kirjallisuus}

BMU. 2007 Erfarungsbericht 2007 zum Erneuerbaren-Energien Gestz (EEG) gemä $§ 20$ EEG - BMUEntwurf. Kurtzfassung. Bundesministerium für Umwelt, Naturschutz und Reactorsicherheit. pp. 43.

ETY. 1991. Council Directive 91/676/EEC of 12 December 1991 concerning the protection of waters against pollution caused by nitrates from agricultural sources. Official Journal L 375, 31/12/1991: 1- 8 . FME. 2002. National inventory report. Finland's report on the greenhouse gas emission inventory to the European commission. Common reporting formats (CRF): 1990 - 2001. Finnish Ministry of Environment. Saatavissa internetistä: http://www.ymparisto.fi/download.asp?contentid=5662\&lan=EN

Hagström, M., Vartiainen, E., Vanhanen, J., 2005. Biokaasun maatilatuotannon kannattavuusselvitys. Loppuraportti. . $77 \mathrm{~s}$..

Huhtanen, P., Nousiainen, J., Rinne, M., 2006. Recent developments in forage evaluation with special reference to practical applications. Agricultural and Food Science 15: 293 - 323.

Huhtanen, P., Rinne, M., Nousiainen, J., 2007. Evaluation of the factors affecting silage intake of dairy cows: a revision of the relative silage dry-matter intake index. Animal 1: $758-770$.

Kalmari, J., 2006. Maatilakohtaisen biokaasulaitosinvestoinnin kannattavuus suomalaisella sikatilalla. Helsingin yliopisto. Taloustieteen laitos. Selvityksiä nro 42: $1-70$.

Kapuinen, P., 1994. Lannankäsittelyn taloudellisuuden ja lannan ravinteiden hyväksikäytön parantaminen. MTT. Vakolan tutkimusselostus 68: $1-90$.

Mattila, P.K., Joki-Tokola. E., 2003. Effect of treatment and application technique of cattle slurry on its utilization by ley. I. Slurry properties and ammonia volatilization. Nutrient Cycling in Agroecosystems 65: 221-230.

Mattila, P.K., Joki-Tokola, E., Tanni, R., 2003. Effect of treatment and application technique of cattle slurry on its utilization by ley. II. Recovery of nitrogen and composition of herbage yield. Nutrient Cycling in Agroecosystems 65: 231-222.

MMM, 2007. Maa- ja metsätalousministeriön asetus maatalouden ympäristötuen perus- ja lisätoimenpiteistä ja maatalouden ympäristötuen erityistuista. Annettu Helsingissä 26. huhtikuuta 2007.

MTT, 2006. The feed tables and Feeding Recommendation 2006. MTT:n selvityksiä 106: 1 - 84

Tyynelä, S, Kapuinen, P., Niemeläinen, O., 2004. Nurmien väkilannoituksen aiheuttamien ympäristöhaittojen vähentäminen sijoituslannoituksen avulla. In: Maataloustieteen Päivät 2004. Suomen Maataloustieteellisen Seuran Tiedote no 19. (Eds. Hopponen, A, Rinne, M.) Published 5.1.2004. Saatavissa internetistä: http://www.smts.fi. ISBN 951-9041-47-8.

VN, 2000. Valtioneuvoston asetus maataloudesta peräisin olevien nitraattien vesiin pääsyn rajoittamisesta 931. Annettu Helsingissä 9. marraskuuta 2000. 